\title{
Mathematics education and the dignity of being
}

\author{
Authors: \\ Paola Valero ${ }^{1}$ \\ Gloria García \\ Francisco Camelo ${ }^{3}$ \\ Gabriel Mancera ${ }^{3}$ \\ Julio Romero ${ }^{3}$ \\ Affiliations: \\ ${ }^{1}$ Department of Learning \\ and Philosophy, Aalborg \\ University, Denmark \\ ${ }^{2}$ Department of \\ Mathematics, Universidad \\ Pedagógica Nacional, \\ Colombia \\ ${ }^{3}$ Faculty of Science and \\ Education, Universidad \\ Distrital Francisco José \\ de Caldas, Colombia

\section{Correspondence to:} \\ Paola Valero \\ Email address: \\ paola@learning.aau.dk \\ Postal address: \\ Sohngaardsholmsvej 2, \\ 9000 Aalborg, Denmark \\ Dates: \\ Received: 14 Apr. 2012 \\ Accepted: 18 Sept. 2012 \\ Published: 15 Nov. 2012 \\ How to cite this article: \\ Valero, P., García, G., Camelo, \\ F., Mancera, G., \& Romero, \\ J. (2012). Mathematics \\ education and the dignity \\ of being. Pythagoras, 33(2), \\ Art. \#171, 9 pages. \\ http://dx.doi.org/10.4102/ \\ pythagoras.v33i2.171
}

(C) 2012. The Authors. Licensee: AOSIS OpenJournals. This work is licensed under the Creative Commons Attribution License.
On the grounds of our work as researchers, teacher educators and teachers engaging with a socio-political approach in mathematics education in Colombia, we propose to understand democracy in terms of the possibility of constructing a social subjectivity for the dignity of being. We address the dilemma of how the historical insertion of school mathematics in relation to the Colonial project of assimilation of Latin American indigenous peoples into the episteme of the Enlightenment and Modernity is in conflict with the possibility of the promotion of a social subjectivity in mathematics classrooms. We illustrate a pedagogical possibility to move towards a mathematics education for social subjectivity with our work in reassembling the notion of geometrical space in the Colombian secondary school mathematics curriculum with notions of space from critical geography and the problem of territorialisation, and Latin American epistemology with the notion of intimate space as an important element of social subjectivity.

\section{Introduction}

We do not need to start this paper with a vivid depiction of the conditions of poverty, violence and disrespect that many students in mathematics classrooms experience in their daily lives. Such situations and the implication of mathematics education in (re)producing them have been documented in research (e.g. Valero \& Pais, 2012). Such situations still exist and justify revisiting the discussion about the connection between mathematics education and democracy in a special issue of a research journal such as Pythagoras. The connection between mathematics education and democracy has been the topic of international journal issues (e.g. ZDM: The International Journal on Mathematics Education 30[6], ZDM 31[1]) and of scattered papers (e.g. De Mattos \& Batarce, 2010; Skovsmose \& Valero, 2008). In the last decade it seems as if topics such as 'equity' and 'social justice' have displaced the discussion about democracy in the mathematics education research literature. Still, the editors of this special issue call researchers to report on the advances in the topic and to explore through theoretical and empirical discussions the significance of the connection between mathematics education and democracy in relation to development.

We have been working in a collaborative team of teachers, teacher educators and researchers grappling with recontextualising the ideas of critical mathematics education as proposed by Skovsmose (1994) and Vithal (2003) to study and transform mathematics education practices in classrooms and schools in so-called 'at risk' communities in Bogotá, Colombia (Camelo, Mancera, Romero, García \& Valero, 2010; García et al., 2009). Attending to the specificities of the context and listening to students and teachers have led us on an intellectual search for a resignification of the possible links between mathematics education and democracy. In the process we drew on diverse sources such as contemporary Latin American philosophy, political and pedagogical literature, critical educational research grounded on the work of Michel Foucault, and critical and political research in mathematics education. Our intention is to bring to international research in mathematics education the discussion of a theoretical framing to rethink the role of school mathematics in constructing historical subjects who strive for living in and with dignity. We build on our research work with teachers and children in communities whose life possibilities are far from reaching the promises of the globalised discourses of social and economic democracy.

We start our article formulating an understanding of democracy in terms of the possibility of a social subjectivity for the dignity of being. We then address the issue of how the historical insertion of school mathematics in relation to the Colonial project of assimilation of Latin American indigenous peoples into the episteme of the Enlightenment and Modernity is in conflict with the possibility of a social subjectivity in mathematics classrooms. We then present the theoretical grid on which we constructed a curricular proposal for working with students in a Colombian classroom on the notion of space. The curricular proposal is an example of an attempt to decentre the core of the mathematics curriculum by opening its possible meanings with other related discursive fields in which notions of space are found. The curricular proposal brings together Euclidean geometry, critical geography and the problem of territorialisation, and contemporary 
Latin American philosophy with the notion of intimate space as an important element of social subjectivity. We argue that such a decentring opens the possibility for forms of subjectivity that are denied in the mainstream mathematics curriculum. We conclude with some remarks about the significance of the types of studies that we have undertaken in contributing to a resignification of the connections between mathematics education and democracy in different historical and geographical contexts.

\section{From democracy to the dignity of being}

Connecting mathematics education and democracy as an idea became possible in mathematics education research in the decade of the 1980s. It is a very recent thought in mathematics education that was made intelligible in the confluence of at least three trends. Firstly, during the 1980s mathematicians and mathematics educators questioned the outcome of the New Maths movement in strengthening the construction of a school mathematics curriculum for an elite of selected students who would continue to study mathematics at a higher level. Concerns for a 'mathematics for all' (Damerow, Dunkley, Nebres \& Werry, 1984) entered the discussion of mathematics educators in a time of consolidation and expansion of educational systems around the world. Secondly, in mathematics education research there has been a growing adoption of sociological and philosophical theoretical frameworks in the study of persistent student failure in mathematics (Lerman, 2000). The sociocultural-political trend in mathematics education research has made it possible to open up the object of research of the field from narrow problems of teaching and learning to understanding them as social practices (Valero, 2010). Thirdly, there was a global trend of making education the pillar of democratisation as expressed by the United Nations Educational, Scientific and Cultural Organisation (UNESCO) in, for example, the global agenda of 'education for all' (UNESCO, 1992). Contrary to previous curricular trends in different countries, this particular international agreement was an attempt for the universalisation of basic education for all children in the world, within a discourse of democratisation and expansion of access to education. It is in the intermesh of these different trends that mathematics education started to be related with power in society, and with the generation and maintenance of mechanisms of in/exclusion. Linking mathematics education to democracy is so recent a formulation that it still may cause many people to wonder. Yet, such an idea has rapidly been adopted in certain research and even policy circles as a new, powerful justification for the needed improvement of educational practices in mathematics classrooms (e.g. Gutierrez, 2010).

The result is the construction of a discourse that posits mathematics education, in the eyes of mathematics educators, as the school subject that can save excluded children from their lack of a future (Lundin, 2012). From policy to research documents, assertions such as 'mathematical (and scientific) competence is the key to the welfare of our nation in a global economy' or 'children who are equipped with better mathematics will have a better future' contribute to selling the myth that mathematics learning can be a way of saving the world, the nation, and the individual. Concomitantly, mathematics education research is positioned to be the scientific discipline with the knowledge, evidence and techniques for achieving such a noble goal (Popkewitz, 2004).

We want to start our rethinking of mathematics education and democracy with the assumption that mathematics education research and practices, if implicated, are neither the cause of nor the solution to the harsh stratification and reduction of millions of people in the world to misery and violent conditions of life. Pais and Valero $(2011,2012)$ have argued that a Political - with capital P - reading of mathematics education treats the different practices that form part of it as economic, social, cultural and historical forms of reasoning and acting. We are compelled to modestly recognise that the redemptive narrative of mathematics education research is no more than an exemplar of a discursive practice that brings forward the privileged function that mathematics as a school subject has performed in the construction of modern, capitalist societies and subjectivities. Failing to do so would allow researchers to keep on disavowing the intricate network of historical, social, political and economic relationships in which mathematics teaching and learning are constantly formed.

Democracy as the striving for a chance of a dignified life is therefore a task to which mathematics educators can contribute a grain of sand only. Nevertheless, even such a minute contribution is worth the effort of thinking it through. It provides an entry into a way of thinking about how mathematics education is one of the areas of the school curriculum that, as we will argue, contributes strongly to the governing of children's conduct.

In particular, in the case of what a striving for 'democracy' may mean in Colombia, we have been confronted with the conflict that emerges between the universalising discourse of 'mathematics for all' as configured in the 1980s and now circulating internationally, and the particular conditions for the creation of a social subjectivity in Colombia. In our research (García et al., 2009) we concluded that any serious attempt to the develop curricular ideas in mathematics for students positioned as excluded had to be woven around their significance for the construction of a social subjectivity. What does this mean? In contrast to other views of curriculum organised around central mathematical ideas or competencies, we proposed the displacement of the core, traditional mathematical concepts as the centre of the curriculum. Such a decentring opens the space for subjectivity to become the articulating axis around which mathematical forms of reasoning and acting could be organised. In making subjectivity an articulating point for the curriculum, it is possible to open up to other forms of being than the ones that are historically and culturally embedded in the traditional mathematics curriculum. 
This displacement emphasises the idea that knowing is not separated from being, an idea that has been recently expressed by socio-cultural theories of mathematics learning (e.g. Radford, 2008), but also by Foucaultian studies of science and education: forms of knowledge are effected and effect power as they bring together knowing and being as two sides of a coin. Forms of knowledge do not only bear the rules of how one knows and what it is to be known, but also impose ways of being on the knowers. Knowing fabricates particular subjectivities through its technologies (e.g. Daston \& Galison, 2007; Popkewitz, 2009). If knowing and being are inseparable, the question emerges of what the forms of knowing and being are that the mathematics curriculum effects in children, and whether those forms of subjectivities are desirable. This becomes a central question of mathematics education seen as a technology of the self (Foucault, 1982), confronted with a desire for 'democracy'.

Zemelman (1997) argues that in the context of Latin American societies and their history, the concept of social subjectivity is an epistemological category that not only points to the necessity of thinking about human beings as necessarily collective beings, but also to the imperative of rethinking social processes on the grounds of the recognition of the multifaceted, complex Latin American reality. In contrast to European notions of the subject as a monadic individual, Zemelman's notion of social subjectivity emphasises the social constitution of concrete historical subjects who articulate time and space for the construction of new, possible projects of a collective future. Against a historical context where colonisation and a colonised education has taught Latin Americans 'how to be a subject that is constantly thinking in being what one is not' (Rivas, 2005, p. 117, our translation), the construction of a social subjectivity, in particular relation to education, is an attempt to make subjects aware of their historical position, for them to know and think the world with others, with the intention of possibly generating new common visions of future conditions of living.

The particular colonial history of Latin America, as varied as it is in the different countries of the continent - as well as distinct from the colonial history of Africa and many Asian nations - not only occupied the minds of the colonised indigenous population. It created historical forms of subjectivities with two main characteristics. The civilising rule of the colonial powers installed successful technologies of the self that generated ideas of the White European as the norm to strive for - thereby abjecting all who are not like the coloniser. Learning to desire assimilation or to be 'what one is not' became a central characteristic of the colonial subjects (Guillén, 1996; Quintar in Rivas, 2005). The other characteristic is that all forms of subjectivity that do not assimilate to the norm and that dare to challenge it need to be silenced and exterminated (Guerra, 1997). Guerra argues that the notion of democracy and citizenship that emerged in Latin America during the consolidation of the nation states at the beginning of the 20th century is rooted in an idea of sameness and correspondence. It opposes the ideas of difference, diversity and heterogeneity. Democracy as a form of governmentality - the combination of particular techniques of government and their rationality working at both the level of the individuals and their selves and also at the level of the population (Foucault, 1988; Lemke, 2002) - to reach sameness was clearly a pillar of the flourishing totalitarian regimes in the 1970s. These regimes positioned themselves as 'democratic' because they strove to guarantee a high degree of civil rights for a unified nation. In this way the regimes succeeded effectively in restricting the expression of social subjectivities.

In Colombia, Díaz (2010) claims that the notion of sameness as a central characteristic in the formation of a nation state with a democratic political regime got inserted in the Political Constitution of 1886 through the declaration of Colombia as a nation unified by the Catholic, Apostolic and Roman religion. Furthermore, such a declaration posited the organisation and direction of public education in the hands of the Catholic Church and its various representative orders, in particular the Society of Jesus. Such a configuration guaranteed a laic education for all Colombians. It simultaneously effected the abjection of people with different political, cultural and sexual expressions and orientations.

If these have been the power effects of colonisation, then the challenge of an education that allows reconstructing a social subjectivity is to build a new interpretation of democracy. Rather than keeping on chasing the European and North American ghosts of Freedom, Equality, and Fraternity, democracy can be thought of as striving for respect for difference and multiple possible senses of future. Democracy is about reclaiming the right of being in dignity what one socially is and could potentially be on the grounds of one's reality.

\section{From mathematics to social subjectivity with mathematics}

The expansion of school mathematics education and its particular unfolding in countries such as Colombia cannot be separated from the history of Spanish colonisation (from the 16th to beginning of the 19th century) and the formation of an independent national state (from the 19th to mid-20th century) (Meyer, Ramirez \& Soysal, 1992). As part of the colonial power, the teaching of mathematics in the territory now identified as Colombia was made possible by the Royal Botanical Expedition. The expedition was a large 'scientific' enterprise in the Americas that, side by side with the economic exploitation of the new continent, intended to document for the European naturalists - headed by the Swede Karl Linnaeus - the botanical wonders of the New World. José Celestino Mutis, Spanish medical doctor, mathematician and Jesuit priest, came to the Americas as the personal physician of the viceroy and was commanded to lead the Royal Botanical Expedition. He is recognised as having started the first course in mathematics at the 'Colegio Mayor de Nuestra Señora del Rosario' in 1761 (Sánchez \& Albis, 2012). For a naturalist like José Celestino Mutis, mathematics was important as a reasoning method and a practical tool for all people: 'peasants, citizens, plebeian, courtiers, soldiers, artificers. Wise, secular, ecclesiastic, all in a word no matter 
condition and status should devote themselves to such a useful study' (José Celestino Mutis cited in Sánchez \& Albis, 2012, p. 110). The tools of mathematics were essential in the effort to create generalised, ideal typologies of natural species that reflected the epistemological virtue of 'scientists' at that time (Daston \& Galison, 2007). The entry of mathematics as part of the commitment of the Spanish Catholic colonisers to evangelise the indigenous populations - and the economic exploitation of natural resources - went hand in hand with the insertion of the colonised in the European, classical episteme (Foucault, 1971) within which scientific rationalities and discourse were configuring in the second half of the 18th century.

In a historiography of mathematics teaching in Colombia, Sánchez and Albis (2012) show how, from its very beginning, mathematics teaching mainly at universities was strongly associated with how the prominent figures of Colombian society - a creole elite descending from Spanish ancestors - strove to bring the country in pace with the thinking of the European and later North American powers. From the middle of the 19th century to the beginning of the 20th century, the vision of the construction of a nation state that had to promote economic development through the advancement of engineering for the taming of Colombia's tropical nature was associated with the placing and growth of mathematics in the Military School and, later on, in the new National University of Colombia. In that context, the discussions on the role of mathematics for the development of the country can be interpreted as that element through which rational and scientific thinking was to be brought to the population. Furthermore, the expansion of mathematics from universities to schools also represents the move towards the insertion of as many people as possible into the Modern episteme. The teaching and learning of mathematics as a school subject for the masses is a recent invention that is related to the universalisation of education at the beginning of the 20th century (Radford, 2004).

Popkewitz (2008) has studied the effects of education and educational sciences into the constitution of the cosmopolitan citizen of Modernity in the USA during the 20th century. Cosmopolitanism refers to the 'Enlightenment's hope of the world citizen whose commitments transcended provincial and local concerns with ideal values about humanity' (p. 1). The school mathematics curriculum is a powerful technology of the self. The technologies of the self are the techniques that human beings have historically developed in practice to understand themselves as human. These technologies:

permit individuals to effect by their own means, or with the help of others, a certain number of operations on their own bodies and souls, thoughts, conduct, and way of being, so as to transform themselves in order to attain a certain state of happiness, purity, wisdom, perfection, or immortality. (Foucault, 1997, p. 225)

Thinking with Foucault, whilst the school mathematics curriculum seems to teach children a valued and useful knowledge, it primarily teaches all of the people involved particular ways of being a subject. It embodies and makes available the cosmopolitan forms of reason, which build on the belief of science-based human reason having a universal, emancipatory capacity for changing the world and people. Human agency, the hope for progress, science as a means to direct and achieve progress, and planning of time result in a thesis about who is the human subject: the being with a 'homeless mind' (Popkewitz, 2008, p. 29). The homeless mind is a type of 'individuality that is both an object and a subject of reflection' and that places 'individuals in a relation to transcendental categories that seem to have no particular historical location or author to establish a home' (Popkewitz, 2008 , p. 30). This thesis is made possible, amongst others, when quantification operates the displacement from qualities of knowing to quantities that can be operated and modelled as facts, as well as when science - both the natural and the human sciences at that time under configuration in their current divisions - makes of the world of things and humans an object of reflection and planning. The mathematics curriculum as a school subject at that time - and still today became one of those areas of schooling that most effectively could 'enlighten' all population into this type of being. From the turn of the 19th century to current times the mathematics curriculum is an important technology of the self that inserts subjects into the forms of thinking and acting needed for people to become the ideal cosmopolitan citizen.

If we look at the particular history of Colombia, the ideal of the cosmopolitan subject of Europe and the USA travel to and become reinscribed in the particularities of Colombian history. Here it is important to point out that in the history of the USA, the reformist education agenda was attached to the Lutheran narrative of redemption for the growing urban population. On the other hand Colombian education was entrusted to the Society of Jesus in its mission of Catholicising and evangelising the native indigenous population (Ahern, 1991). The political alliance between colonial power and the Catholic Church was a doubly effective strategy for not only subordinating the colonised to a new rule, but above all, for Europeanising them through making them loyal to God and the Spanish Crown (Herrán, 1998).

In the second place, the process of consolidation of a nation state in the 1960s was closely connected to the advance of the agendas of international cooperation for development and modernisation from international agencies such as the World Bank. In her study of the mathematics curriculum in Colombia, García (2003) argues that in the 1960s the national government responded to the crucial challenges of school drop-outs caused by the enlargement of coverage given the changes in the distribution of the population from rural to new urban masses. The response to both expand and strengthen education followed development policies of international agencies that pushed the adoption and implementation of technocratic planning strategies in education. Good education for development meant not only the political and administrative steering of education for the needs of economic and social development in the country, but also the introduction of educational technology to make the processes of education more effective, flexible and constantly educational. A few years later, this formulation became 
clearer when educational effectiveness - qualitatively and quantitatively - was also connected to the optimisation of investment in education. In this way the whole logic of education for development as part of the steering of the state was accompanied by concrete educational technologies governing children's conduct.

These two trends were epitomised some years later in the formulation and implementation of the Curricular Renovation in the 1980s. The first unified school mathematics curriculum was formed under the leadership of Carlos Eduardo Vasco. Being a philosopher and mathematician, having pursued graduate studies in the USA and Germany, and belonging to the Society of Jesus, Carlos Vasco was consultant for the Colombian Ministry of Education from 1978 to 1993. He was in charge of the first systematic attempt to spread psychologybased ideas about mathematics education amongst teachers (Molano, 2011).

The new technology of school mathematics was called the 'system approach', and it was meant to be differentiated from other attempts to include a Modern mathematics approach to school mathematics in Colombia. The system approach defined a system (S) as a set of objects and their relations and operations. Every mathematical system may be defined in terms of a subset of objects (A), a subset of operations $(\mathrm{O})$, and a subset of binary relations between the objects of $A,(R)$. In general terms, a system may be defined as $S=(A, O, R)$. The curriculum for school mathematics proposed to work with eight kinds of systems: number systems, geometric systems, metric systems, data systems, set systems, operations and relations systems, and analytical systems (MEN, 1991, pp. 9-17). As a complement of this ontology of school mathematics, its epistemology was founded on Jean Piaget's ontogenetic epistemology as a theory of child development that could be operationalised to think about children's cognitive development in mathematics. The Curricular Reform of the 1980s in Colombia was possible in the confluence of different theses about the hope for a new, mathematically competent, modernised Colombian child who could become the cosmopolitan citizen needed for the progress of the country. Mathematics education technology entered the administration of schoolchildren with the double authority of mathematics, cognitive psychology and educational research, under the leadership of a Jesuit priest.

Since the 1980s the official Colombian school mathematics curriculum has incorporated the notions that travel around the international discussions on mathematics education research, as well as the global trends of national education. The epistemologies available for the curriculum remain rooted in constructivist theories of learning derived from Piagetian ontogenetic epistemology. New curricular reforms have brought the language of 'outcomes-based education' in the 1990s, associated to the era of Unesco's plan Education for all (Valero, 2007). More recently, the language of competences and standards inserted in the logic of the Organisation for Economic Co-operation and Development (1989, 2001) have found their way into curricular documents. As new discourses are reconfigured and some elements apparently displaced, there is continuity in the fundamental assumption that mathematics education is about the fabrication of the rational, effective, global cosmopolitan child of the 21st century.

So far we have argued that, from its very introduction in Colombia, mathematics education has contributed to fabricating particular historical subjects as part of its insertion in the colonial and national project of assimilating the culture, the economy, the political regime and also citizens into the developed, scientific Western, Modern world. At this stage many people would think: But what is the problem? That is an aim to reach and it is only desirable that mathematics education fulfils such social role. As León and Zemelman (1997) point out, the problem is that the faithful allegiance of Latin American elites to the order historically established by the White European rationality has reduced any other form of being to that of an undignified existence, prevented from doing and enacting its own history. The system of reason of Modernity and its current manifestations render it almost impossible to construct a social subjectivity based on the dignity of being Latin American, or being Colombian.

When played in the terrain of school mathematics practices, the educational technologies that insert pupils in the grid of the Modern, cosmopolitan and now global subject, effect the abjection of all those who do not conform to the norm by singling out who and how those who are different need to be brought into redemption. Popkewitz (2008) argues that any cultural thesis about the subjects of schooling produce abjections. Abjection is the way that exclusion is generated as the effect of defining the norm for inclusion and its hope for those who are not part of that norm. When the curricular guidelines in mathematics declare the hope for the future rational, cosmopolitan citizens, they are at the same time declaring who is not seen as being part of those who comply with the norm. The mathematics curriculum, as a technology of the self, brings about compliance with the norm in children's minds, bodies and conduct, and thus operates inclusions and exclusions.

\section{From mathematical spatiality to social space and intimate space}

In the case of the schools, children and teachers that we have been working with, the existence of a deficit discourse on the students who live in the misery belt of Bogotá is an expression of the effective use of the tools of mathematics educational technologies not only to teach children mathematics, but also to create a clear position of exclusion for them. Teachers collectively constructed the class 703 - Grade 7, group 3 as those who 'have low values', 'have little interest in their learning, especially in the learning of mathematics' and:

\footnotetext{
... do not have a defined centre of attention and their dispersion generates a complicated dynamic in the classroom. They run over those students who have the desire of getting involved in the activities proposed. (García et al., 2009, p. 18)
} 
Such discourse embeds in itself the thesis that the ideal school child is one with 'high values', who is interested in learning mathematics, who respects other children, and who gets involved in the proposals of the teachers. In other words, the normal, desired child is a child who has learned to be and behave according to the norms of some kind of middle class, 'culturised' people. In this way the children in class 703, their families, and their experiences are positioned as deviant and in need of remediation and salvation. In this case, most teachers found the children so 'deviant' that they had given up on them.

It was far more than evident that the exclusion of these students was already operated in the constant contrast between teachers' expectations of the children being rational, cognitive children against the students' engagement in the world. The issue at stake then became how we could possibly engage as teachers and as researchers in going beyond our understanding of that situation, and how we could engage students recovering one thing: their dignity of being the social, historical human beings that they were, with a possibility of imagining a future.

In what follows we do not want to play the saviour of the children of class 703. In fact, one year after our work at the school took place, some of the teachers involved in our team left the school for other jobs, the school principal was replaced, and very probably, the whole situation returned to what it was. Elsewhere (e.g. Camelo et al., 2010; García et al., 2009) we have reported the design of teaching sequences that built on Skovsmose's (2001) landscapes of investigation as an important tool for realising into practice some of the concerns of critical mathematics education. In this article, we depart from that literature to reinterpret the design and activities from the point of view of the conflict between the subjectivities that the mathematics curriculum offers, and the possibility of a mathematics education for a social subjectivity.

As mentioned previously, class 703 was the 'problem class' of the school: the headache of all teachers. It was a group of 39 Grade 7s, whose age varied between 11 and 15 years. The school was located in an area at the outskirts of Bogotá, where some years ago there were fields which developed into shantytowns of people displaced to the big city due to the many sources of violence in the Colombian countryside.

For conducting this participatory research all the ethical considerations related to the involvement of teachers and students were followed. Teachers and students participated voluntarily. The teachers involved were also part of the collaborative research team. Children and their parents were informed and asked for permission to participate. In the following account we keep the names of the teachers, since they are the same researchers, but we keep anonymous the names of the children.

When we started our work at the school in 2008, Francisco Camelo was a mathematics teacher there. Together with other teachers in mathematics, science, biology and physical education, Francisco has been challenging the statement that 'there was nothing to do with these kiddos'. The concept of students' foregrounds (Alrø, Skovsmose \& Valero, 2008; Skovsmose, 2005) allowed us at that time to move away from a deficit explanation of children's 'disengagement' with school mathematics and education on the grounds of the lack in their background. Instead, the possibility of thinking about the relationship between students' engagement in their (mathematics) education and their interpreted possibilities of future was an alternative.

We faced the challenge of conceptualising and performing mathematics teaching or learning units that built on the students' foregrounds and that introduced them into a landscape of investigation. How to do that? Where to start? 'Listen to the students, ask them about their lives and don't imagine what may be interesting for them', Paola Valero reminded all in the research team. 'The concept of space is important in mathematics. Why don't we start there?' Gabriel Mancera mooted an idea. The idea resonated with Gloria García. She was part of a research group with critical geographers and was participating in a discussion on representations of time of space and the construction of territorial identities. Gonzalo Peñaloza thought this idea could be connected with his experience of working with social cartography with teachers in Bogotá, as a way for teachers and students to inquire about the school community, the children and the problems that could generate interdisciplinary learning and social action (Peñaloza et al., 2006). It seemed that the idea of space could be fruitful as a basis for creating a scenario for mathematics learning. Reaching this choice was not a straightforward decision. There were many discussions, readings and interpretations amongst the research team that made possible the configuration of that idea.

According to the Colombian Curricular Guidelines (National Ministry of Education of Colombia [MEN], 1991), the mathematics curriculum in secondary schools should promote notions of space in Euclidean geometry and to a lesser extent in projective geometry. The curricular contents tend to be reduced to the establishment of geometric figures and their properties. In Euclidean geometry, space is constructed on the grounds of the reflection on the properties of geometrical shapes, made evident through the use of ruler and compasses. Combined with the Cartesian coordinate system, it allows one to think about space as a system of positions that can be described in a precise and uniform way (Gálvez, 1985). Projective geometry invites an active exploration of tridimensional space in an external or imagined reality, and through the representation of solid objects in space. The guidelines describe the cognitive processes that children need to attain as a result of the teaching of central notions of Euclidean and projective geometry in defining space:

It is expected that students move from an intuitive or sensorimotor understanding of space (related to the practical capacity to act in space, to manipulate objects, and to locate them in an environment) towards a conceptual and abstract space related to the capacity of representing internally the space. (MEN, 1991, p. 56) 
The concept of space to be reconstructed in the students' understanding is that of a rational, referential space with fixed points in two or three dimensions. It is assumed that the conceptual development of the child will lead to an internal and abstract representation which will contribute to making a decontextualised child, freed from the practical capacities of acting with objects in space, particularly of those spaces where everyday life occurs.

It is evident that the curricular view of space and spatiality was in sharp contrast with the experience of many of the students in the class 703. Their personal history in the neighbourhood was that of a social space in a geographical location in transformation by the practices of living and surviving, filled with the bad smells of one of the largest city landfills in the vicinity. Feelings of detachment and attachment to new geographical locations due to the forced or voluntary displacement from the hometowns or homelands to the big city due to political violence were part of children's lives. The intimate spaces where some children had learnt to be were far more filled with dirt, bodies, practices, conflicts and feelings than the clean spaces invoked by the Euclidean space promoted by school mathematics.

In our work the issue of how to articulate a teaching or learning experience in mathematics classrooms that could allow students to go beyond the Modern subjectivity towards a social subjectivity took form in a new conceptual grid, enabling us to think of space as incorporating the children's social experience of space. Skosvmose's suggestion of building semantic fields for organising open, landscapes of investigation (Skovsmose, 1994) was a starting point that allowed us to bring together two additional perspectives on space. The Euclidean and projective geometrical space was reconfigured with the notion of territorialisation of critical geography, and the notion of intimate space in Latin American social epistemology. Seen retrospectively, the reconfiguration of the notion of space with these two other semantic spaces on 'space' can be reformulated as an attempt on our side to decentre the notion of Euclidean space as the core, fundamental way of thinking about space that is part of a traditional, mathematics-centred curriculum. We concur with Deleuze and Guattari (1987) on the strategy of decentring the mathematical core notions of the curriculum by displacing their meaning into related though nonmathematical semantic fields. The strategy of decentring is a conscious attempt from our side to articulate the curriculum around the construction of subjectivity. In the displacement of a unified and unique notion of space, students were invited to fill with their bodies, experiences and practices the clean, empty void of school Euclidean space, thus allowing the possibility of being and knowing who they are, and of imagining their future.

Contemporary social theory has reclaimed the thinking about space from the regime of mathematisation to the field of political, economic and historical thinking (e.g. Lefèbvre, 1991). Such displacement has affected traditional geographical discourses, making possible the emergence of critical geography and the concern for the inseparability of physical and geographical space from the practices and processes of social and cultural identity formation and subjectification (e.g. Crang \& Thrift, 2000). In Latin America, critical geography contributes a geopolitical analysis of the relationship between space and power in processes of the organisation of territories locally, regionally and globally. It also addresses the issue of territorial appropriation and representation of different peoples and communities, and the claims to the right to the territory through performing critical, social cartographies based on participatory information systems (Delgado, 2006).

The notion of intimate space (Tapia, 1997), rooted in contemporary Latin American philosophy, allowed us to connect the relevance of thinking about space, spatiality and the construction of a social subjectivity. Following the recovery of space as an important category for thinking about society and practice, Tapia asserts that a social space as a possibility of constituting a material and cultural world - unfolds from the relationship between the Self and the Others when different positions are shaped and delimited. Thus, analysing the social space is a matter of 'ordering correlative positions, that is, ordering coexistences' (p. 159). Becoming subject means a double move of recognition of otherness and recognition of the self. The possibility of a social subjectivity therefore also requires an intimate space of action but in full awareness of the other. This is different from, say, an individual space which could tend to be closed in itself. The intimate space is close to the subject but in coexistence with the other.

The thinking about space in the connections between these three related semantic fields -geometrical space, territorialisation, and intimate space - led us to propose to students a quite different learning landscape than the one made available by the traditional mathematics curriculum. We established three entry points into the learning landscape: Who am I? Who are we as members of class 703 in our school? Who are we as inhabitants of this locality in the capital city? Each one of these entry points, besides being thought of as a field for learning, was also thought of as a 'nodal point' of social subjectivity which, according to Zemelman (1997, p. 30 ), allows connecting intimate spaces of being to collective spaces of action for the search for a different viable future.

In each nodal point a series of activities combined different mathematical notions related to space as well as many other topics of the curriculum. However, the mathematical activity was always carried out allowing connections to the students' experiences in the family, in the school and in the locality. For example, in the first nodal point 'Who am I?' students were asked to write a story about themselves in their family. Jeimy, one of the students, wrote:

Before there were huts made of hay with no public services before there were no paved streets and before there were less people. Now there are public services the houses have one or two floors there are more people 128 parcels before there were fewer the neighbourhood has public lighting we still miss the pavement 
in the streets and to have a park were we children can have fun and improving the community room to have a community dining room and some other necessities that we all our hope for. (Jeimy's letter in the activity 'Who am I', our translation).

The personal and family histories were connected to the growth of the locality and the territorialisation of that space in the communities where students live. Google Earth was used as a tool for locating important sites of practice. The maps were used for tracing the paths and movements that students usually perform in their locality. The maps also brought together the practices of the communities around the school with the practices of the children and their families. Many students could locate their houses and make sense of the relationship between them, their families, the school, the economic activities in the locality, and even sites and practices that threatened them - such as drug distribution, the activities around the huge sanitary filling in the locality, et cetera.

In each nodal point, moving between mathematisations, socially constituted geographical spaces and the closeness with the experience of children was a strategy for decentring the sense of space as a clean, abstract mathematical object.

\section{Social subjectivity for the dignity of being with mathematics}

There could be many ways of thinking about the relationship between mathematic education and democracy. We have argued that any attempt at theorising about such an idea and attempting to realise it in educational practice needs to consider the effects of power of the school mathematics curriculum in promoting the rational, objective, homeless, cosmopolitan subject of Modernity. The thesis of the mathematically competent child, however, is inscribed in particular times and spaces. Thus, there is no universal analysis of how the school mathematics curriculum is fabricating subjects. We need to pay attention to the study of the cultural histories of the constitution of what counts for democracy and in which conditions of possibility mathematical subjectivities are inscribed in national histories. If retaking the issue of mathematics education and democracy intends to be a move beyond redemptive discourses of empowerment with and through mathematics that effect a clear abjection of all those children whose forms of life and experience do not align with those of the cosmopolitan child, then we need to consider seriously how we wish to understand democracy and mathematics education at each historical point and society.

In Colombia it was evident to us that the forms of knowing and being made available by the national curricular guidelines in mathematics were implicated in the systematic exclusion of children who did not fit the norm established by the thesis of the child as an abstract, Piagetian cognitive agent on which the curriculum was intended to operate. We decentred the key concepts of the mathematics curriculum such as that of space in an attempt to facilitate the emergence of social subjectivities. The decentring of the school mathematics curriculum may open the possibility for an educational project in mathematics that allows for different subjectivities. Such a possibility is precisely an alternative for a democracy that reclaims the dignity of being.

\section{Acknowledgements}

This article is part of the Study of learning environments in mathematics and exclusion processes in the classroom project funded by the Colombian Institute for the Advancement of Science and Technology (COLCIENCIAS). The project is supported by the Universidad Pedagógica Nacional de Colombia, Universidad Distrital de Bogotá, and Aalborg University in Denmark.

The article is the result of many years of collaborative research, together with other teachers and teacher educators such as Gonzalo Peñaloza, Sandra Samacá, Claudia Salazar and Maria Rosa González. We also thank the undergraduate and graduate students who have participated with us in the work in the schools that make part of the project.

We thank Thomas Popkewitz and the Wednesday Group at the University of Wisconsin, USA, Gelsa Knijnik from Unisinos, Brazil, and the members of the SMERG group at Aalborg University, Denmark for their comments on previous drafts of this article.

\section{Competing interests}

The authors declare that they have no financial or personal relationship(s) which may have inappropriately influenced them in writing this article.

\section{Authors' contributions}

G.G. (Universidad Pedagógica Nacional) is the project leader. G.G., F.C., G.M. and J.R. (Universidad Distrital Francisco José de Caldas) were involved in the project through developing the curriculum design and collecting information. P.V. (Aalborg University) has contributed to the theoretical development of the project and wrote the manuscript, with inputs from all the authors.

\section{References}

Ahern, E. (1991). El desarrollo de la educación en Colombia: 1820-1850 [The development of education in Colombia: 1820-1850]. Revista Colombiana de Educación, 22-23.

Alrø, H., Skovsmose, O., \& Valero, P. (2008). Inter-viewing foregrounds: Students' motives for learning in a multicultural setting. In M. César, \& K. Kumpulainen (Eds.), Social interactions in multicultural settings (pp. 13-37). Rotterdam: Sense Publishers.

Camelo, F., Mancera, G., Romero, J., García, G., \& Valero, P. (2010). The importance of the relation between the socio-political context, interdisciplinarity and the learning of the mathematics. In U. Gellert, E. Jablonka, \& C. Morgan (Eds.), Proceedings of the 6th International Mathematics Education and Society Conference, Vol. 1 (pp. de/en/v/mes6/documents/proceedings/Band_1_Finale.pdf

Crang, M., \& Thrift, N.J. (2000). Thinking space. London: Routledge.

Damerow, P., Dunkley, M., Nebres, B., \& Werry, B. (Eds.). (1984). Mathematics for all. Paris: UNESCO.

Daston, L., \& Galison, P. (2007). Objectivity. New York, NY: Zone Books, distributed by MIT Press.

De Mattos, A., \& Batarce, M. (2010). Mathematics education and democracy. ZDM: The International Journal on Mathematics Education, 42(3), 281-289. http:// dx.doi.org/10.1007/s11858-009-0232-2 
Deleuze, G., \& Guattari, F. (1987). A thousand plateaus: Capitalism and schizophrenia. Minneapolis, MN: University of Minnesota Press.

Delgado, O. (2006). Debates sobre el espacio en la geografía contemporánea. Bogotá: Universidad Nacional de Colombia.

Díaz, A. (2010). Democracia y nación en el siglo XIX colombiano. Available from http:// www.revistalaciudad.com/

Foucault, M. (1971). The order of things. An archaeology of the human sciences (April 1994 edn.). New York, NY: Vintage Books.

Foucault, M. (1982). The subject and power. Critical Inquiry, 8(4), 777-795. http:// dx.doi.org/10.1086/448181

Foucault, M. (1988). The political technology of individuals. In L. H. Martin, H. Gutman, \& P.H. Hutton (Eds.), Technologies of the self: A seminar with Michel Foucault (pp. 145-162). Amherst, MA: University of Massachusetts Press.

Foucault, M. (1997). Technologies of the self. In M. Foucault, \& P. Rabinow (Eds.), Ethics: Subjectivity and truth (pp. 223-251). New York, NY: The New Press.

Gálvez, G. (1985). El aprendizaje de la orientación en el espacio urbano. Una proposición para la enseñanza de la geometría en la escuela primaria. Unpublished doctoral dissertation. Centro de Investigación y de Estudios Avanzados del Instituto Politécnico Nacional, Mexico.

García, G. (2003). Currículo y evaluación en matemáticas. Un estudio en tres décadas en la educación básica (1st edn.). Bogotá: Cooperativa Editorial Magisterio.

García, G., Valero, P., Camelo, F., Mancera, G., Romero, J., Peñaloza, G., et al. (2009). Escenarios de aprendizaje de las matemáticas. Un estudio desde la perspectiva de la educación matemática crítica. Bogotá: Universidad Pedagógica Nacional de Colombia.

Guerra, C. (1997). Hacia una sociología del sujeto: Democracia y sociedad civil. In E. León, \& H. Zemelman (Eds.), Subjetividad: Umbrales del pensamiento social (pp. 107-136). Barcelona: Anthropos.

Guillén, F. (1996). El poder político en Colombia (4th edn.). Bogotá: Planeta.

Gutiérrez, R. (2010). The sociopolitical turn in mathematics education. Journal for Research in Mathematics Education, 41(Special Equity Issue), 1-32.

Herrán, M. (1998). Fundación del Colegio Máximo de la Compañía de Jesús y el Colegio de San Bartolomé en el Nuevo Reino de Granada [Foundation of the Higher School of the Society of Jesus and the School of San Bartolomé in the Kingdom of Nueva Granada]. Historia de la Educación Colombiana, 1, 9-35.

Lefèbvre, H. (1991). The production of space. London: Blackwell.

Lemke, T. (2002). Foucault, governmentality, and critique. Rethinking Marxism, 14(3), 49-64. http://dx.doi.org/10.1080/089356902101242288

León, E., \& Zemelman, H. (1997). Subjetividad: Umbrales del pensamiento social. Barcelona: Anthropos.

Lerman, S. (2000). The social turn in mathematics education research. In J. Boale (Ed.), Multiple perspectives on mathematics teaching and learning (pp. 19-44) Westport, CT: Ablex Publishing.

Lundin, S. (2012). Hating school, loving mathematics: On the ideological function of critique and reform in mathematics education. Educational Studies in Mathematics, 80(1/2), 73-85. http://dx.doi.org/10.1007/s10649-011-9366-6

MEN [National Ministry of Education of Colombia] (1991). Marco general de matemáticas. Propuesta de programa curricular para noveno grado. Bogotá: MEN.

Meyer, J.W., Ramirez, F.O., \& Soysal, Y.N. (1992). World expansion of mass education 1870-1980. Sociology of Education, 65(2), 128-149. http://dx.doi.org/10.2307 /2112679

Molano, M. (2011). Carlos Eduardo Vasco Uribe. Trayectoria biográfica de un intelectual colombiano: Una mirada a las reformas curriculares en el país [Carlos Educardo Vaso Uribe. Biographic trajectory of a Colobian intellectual: A look at curricular reforms in the country]. Revista Colombiana de Educación, 61, 161-198.

Organisation for Economic Co-operation and Development. (1989). Education and the economy in a changing society. Paris: OECD.

Organisation for Economic Co-operation and Development. (2001). Knowledge and skills for life. First result from the OECD Programme for International Student Assessment (PISA) 2000. Paris: OECD. Available from http://www.oecd.org/ dataoecd/44/53/33691596.pdf
Pais, A., \& Valero, P. (2011). Beyond disavowing the politics of equity and quality in mathematics education. In B. Atweh, M. Graven, W. Secada, \& P. Valero (Eds.) Mapping equity and quality in mathematics education (pp. 35-48). New York, NY: Mapping
Springer.

Pais, A., \& Valero, P. (2012). Researching research: Mathematics education in the political. Educational Studies in Mathematics, 80(1), 9-24. http://dx.doi.org/ 10.1007/s10649-012-9399-5

Peñaloza, G., Boada, M., Acosta, M. G., Becerra, J., Galeano, J., \& Gallego, C. (2006) Territorio y territorialidades en La Candelaria. Bogotá: Secretaría de Educación de Bogotá.

Popkewitz, T.S. (2004). The alchemy of the mathematics curriculum: Inscriptions and the fabrication of the child. American Educational Research Journal, 41(1), 3-34. http://dx.doi.org/10.3102/00028312041001003

Popkewitz, T.S. (2008). Cosmopolitanism and the age of school reform: Science, education, and making society by making the child. New York, NY: Routledge.

Popkewitz, T.S. (2009). Curriculum study, curriculum history, and curriculum theory: The reason of reason. Journal of Curriculum Studies, 41(3), 301-319. http:// dx.doi.org/10.1080/00220270902777021

Radford, L. (2004). From truth to efficiency: Comments on some aspects of the development of mathematics education. Canadian Journal of Science, Mathematics and Technology Education, 4(4), 551-556. http://dx.doi.org/10.1080/ 14926150409556635

Radford, L. (2008). The ethics of being and knowing: Towards a cultural theory of learning. In L. Radford, G. Schubring, \& F. Seeger (Eds.), Semiotics in mathematics education: Epistemology, history, classroom, and culture (pp. 215-234). Rotterdam: Sense Publishers.

Rivas, J. (2005). Pedagogía de la dignidad de estar siendo. Entrevista con Hugo Zemelman y Estela Quintar [Pedagogy of the dignity of being]. Revista interamericana de educación de adultos, 27(1), 113-140.

Sánchez, C.H., \& Albis, V. (2012). Historia de la enseñanza de las matemáticas en Colombia. De Mutis al siglo XXI [History of mathematics teaching in Colombia. From Mutis to the XXI Century]. Quipu, 14(1), 109-157.

Skovsmose, O. (1994). Towards a philosophy of critical mathematics education. Dordrecht: Kluwer Academic Publishers.

Skovsmose, O. (2001). Landscapes of investigation. ZDM: The International Journal on Mathematics Education, 33(4), 123-132. http://dx.doi.org/10.1007/BF02652747

Skovsmose, O. (2005). Foregrounds and politics of learning obstacles. For the Learning of Mathematics, 25(1), 4-10. http://www.jstor.org/stable/40248476

Skovsmose, O., \& Valero, P. (2008). Democratic access to powerful mathematical ideas. In L.D. English (Ed.), Handbook of international research in mathematics
education. Directions for the 21 st Century (2nd edn., pp. 415-438). Mahwah, NJ: education.

Tapia, M. (1997). El espacio íntimo en la construcción intersubjetiva. In E. León, \& H. Zemelman (Eds.), Subjetividad: Umbrales del pensamiento social (pp. 153-170). Barcelona: Anthropos.

UNESCO. (1992). Education for all: An expanded vision. Paris: UNESCO.

Valero, P. (2007). In between the global and the local: The politics of mathematics education reform in a globalized society. In B. Atweh, A. Calabrese Barton, $\mathrm{M}$. Borba, N. Gough, C. Keitel, C. Vistro-Yu, et al. (Eds.), Internationalisation and globalisation in mathematics and science education (pp. 421-439). New York, NY: Springer. http://dx.doi.org/10.1007/978-1-4020-5908-7 23

Valero, P. (2010). Mathematics education as a network of social practices. In V. Durand-Guerrier, S. Soury-Lavergne, \& F. Arzarello (Eds.), Proceedings of the Sixth Congress of the European Society for Research in Mathematics Education (pp. LIVLXXX). Lyon: Institut National de Récherche Pédagogique.

Valero, P., \& Pais, A. (2012). Mathematics education between utopia and reality: Examining research in contexts of conflict, poverty and violence. In A. Halai, \& D. Wiliam (Eds.), Research methodologies from the 'South' (pp. 159-177). Karachi, Pakistan: Oxford University Press.

Vithal, R. (2003). In search of a pedagogy of conflict and dialogue for mathematics education. Dordrecht: Kluwer Academic Publishers. http://dx.doi.org/10.1007/ 978-94-010-0086-4

Zemelman, H. (1997). Sujetos y subjetividad en la construcción metodológica. In E. León, \& H. Zemelman (Eds.), Subjetividad: Umbrales del pensamiento social (pp. 21-35). Barcelona: Anthropos. 